\title{
REALISASI DESAIN RUANG PUBLIK TERPADU RAMAH ANAK DI LINGKUNGAN PADAT PENDUDUK PADA ERA PANDEMI COVID-19
}

\author{
Fery Mulya Pratama', Nia Suryani ${ }^{2}$ \\ ${ }^{1}$ Universitas Indraprasta PGRI, Program Studi Arsitektur \\ pratama.ars@gmail.com \\ 2Universitas Indraprasta PGRI, Program Studi Arsitektur \\ niasuwardi@gmail.com
}

\begin{tabular}{ll}
\hline Informasi artikel \\
\hline Sejarah & \\
artikel: & \\
Diterima & 26 Maret 2021 \\
Revisi & 29 Maret 2021 \\
Dipublikasikan & 30 Maret 2021 \\
\hline Kata kunci: & \\
realisasi & \\
ruang bermain & \\
anak & \\
ruang public & \\
pandemi &
\end{tabular}

\begin{abstract}
ABSTRAK
Adanya kebutuhan Lingkungan RT 04/06 terhadap fasilitas ruang publik yang dapat menampung kegiatan bermain anak serta interaksi warga karena sebelum di kawasan permukiman ini hampir semua kegiatan interaksi warga seperti ibuibu mengobrol, anak-anak bermain serta bapak-bapak minum kopi bersama banyak dilakukan di teras rumah warga, jalan lingkungan, atau bahkan hanya di pos ronda yang tidak digunakan di siang hari. Anak-anak sering kali bermain di jalan dengan memanfaatkan saat-saat tidak ada kendaraan yang berlalu hanya sekedar untuk bermain bola, petak umpet, atau bermain lompat tinggi dengan karet. Hal ini tentunya tidak memberikan rasa aman bagi anak-anak dan orang tua serta membatasi kreatifitas dan ruang gerak bagi mereka, belum lagi juga mengganggu laju kendaraan yang melintas di jalan lingkungan permukiman ini. Melihat kondisi tersebut, beberapa tokoh masyarakat dan pemangku kepentingan seperti ketua RT 04 dan tim pengabdi melakukan musyawarah serta diskusi untuk mewujudkan desain RPTRA yang sudah disepakati pada kegiatan pengbadian di tahap sebelumnya. Dari hasil diskusi dan musyawarah tersebut terdapat kesepakatan akan menggunakan sebidang tanah milik warga untuk bisa digunakan sebagai ruang publik sederhana tersebut, namun baik warga maupun tokoh masyarakat ini belum memiliki dana dan tahapan pembangunan agar desain tersebut bisa segera terealisasikan. Sehingga dengan metode partisipatif, tim pelaksana abdimas dan warga bersama-sama menyusun langkah realisasi awal. Langkah yang dilakukan pertama kali karena kondisi pandemi yakni pembuatan RAB dan penentuan porsi andil berbagai pihak dalam pembangunan RPTRA ini.

\section{ABSTRACT}

\section{Key word:}

realization

playground

children

public space

pandemic
There is a need for the RT 04/06 Environment for public space facilities that can accommodate children's play activities and citizen interactions because before in this residential area almost all citizen interaction activities such as mothers chatting, children playing and fathers drinking coffee together were widely carried out on the terraces of residents' houses, neighborhood roads, or even just at the guard post which is not used during the day. Children often play on the road by taking advantage of times when no vehicles are passing just to play ball, hide and seek, or play high jump with rubber. This certainly does not provide a sense of security for children and parents and limits their creativity and space for movement, not to mention that it also disturbs the speed of vehicles passing on this residential neighborhood road. Seeing this condition, several community leaders and stakeholders such as the head of RT 04 and the service team held deliberations and discussions to realize the RPTRA design that had been agreed upon in the previous stage of service activities. From the results of the discussion and deliberation, there was an agreement to use a plot of land belonging to residents to be used as a simple public space, but neither the residents nor the community leaders had the funds and stages of development so that the design could be realized immediately. So that with the participatory method, the community service implementation team and residents together formulated the initial realization steps. The first steps taken due to pandemic conditions were the making of the RAB and determining the portion of the various parties' share in the development of this RPTRA. 


\section{PENDAHULUAN}

\section{Analisis Situasi}

Adanya kebutuhan Lingkungan RT 04/06 terhadap fasilitas ruang publik yang dapat menampung kegiatan bermain anak serta interaksi warga karena sebelum di kawasan permukiman ini hampir semua kegiatan interaksi warga seperti ibu-ibu mengobrol, anak-anak bermain serta bapakbapak minum kopi bersama banyak dilakukan di teras rumah warga, jalan lingkungan, atau bahkan hanya di pos ronda yang tidak digunakan di siang hari.

Anak-anak sering kali bermain di jalan dengan memanfaatkan saat-saat tidak ada kendaraan yang berlalu hanya sekedar untuk bermain bola, petak umpet, atau bermain lompat tinggi dengan karet. Hal ini tentunya tidak memberikan rasa aman bagi anak-anak dan orang tua serta membatasi kreatifitas dan ruang gerak bagi mereka, belum lagi juga mengganggu laju kendaraan yang melintas di jalan lingkungan permukiman ini.

Situasi ini tentunya sudah disikapi oleh tim pengabdi dengan kegiatan PKM pada tahap sebelumnya yakni dengan memfasilitasi warga dalam menghasilkan sebuah desain Ruang Publik Terpadu Ramah Anak (RPTRA) yang bisa mengakomodir kegiatan warga, khususnya anak-anak agar bisa bermain dengan rasa aman yang sebelumnya sulit untuk didapatkan karena tidak ada ruang luar yang bisa memadai kegiatan tersebut.

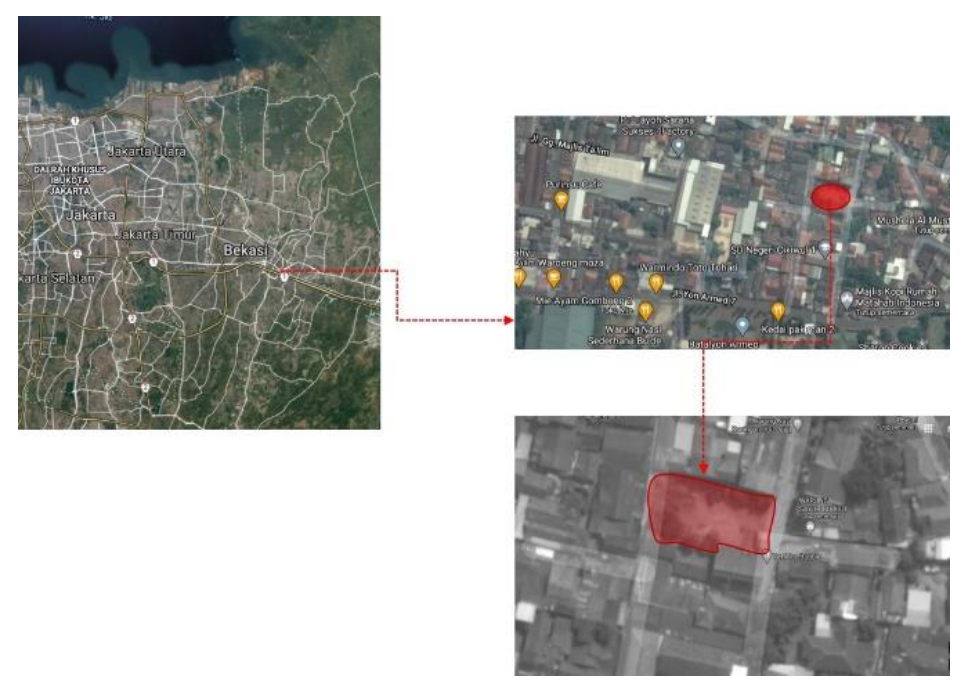

Gambar 1. Peta Lokasi Site yang Dirancang menjadi RPTRA

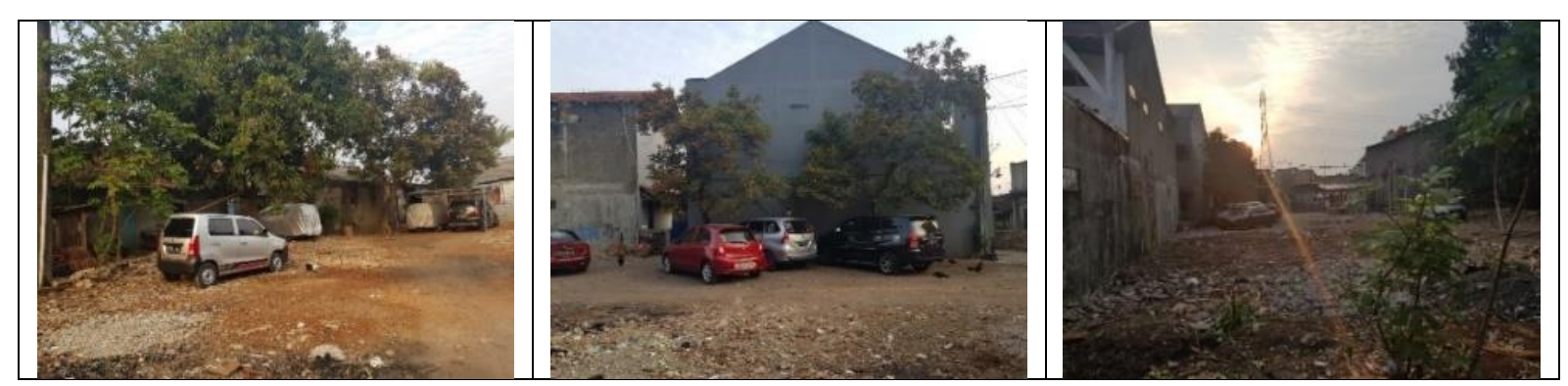

Gambar 2. Kondisi Eksisting dan Lingkungan Sekitar RPTRA 


\section{Permasalahan Mitra}

Melihat kondisi tersebut, beberapa tokoh masyarakat dan pemangku kepentingan seperti ketua RT 04 dan tim pengabdi melakukan musyawarah serta diskusi untuk mewujudkan desain RPTRA yang sudah disepakati pada kegiatan pengbadian di tahap sebelumnya. Dari hasil diskusi dan musyawarah tersebut terdapat kesepakatan akan menggunakan sebidang tanah milik warga untuk bisa digunakan sebagai ruang publik sederhana tersebut, namun baik warga maupun tokoh masyarakat ini belum memiliki dana dan tahapan pembangunan agar desain tersebut bisa segera terealisasikan. Melihat kondisi ini, kami sebagai tim pengabdian masyarakat Universitas Indraprasta PGRI melakukan diskusi dengan Ketua RT 04 RW 06 Kelurahan Cikiwul dan memberanikan diri untuk turut andil dalam merealisasikan desain RPTRA tersebut dalam kegiatan pengabdian masyarakat dengan judul PKM Realisasi Desain RPTRA di Lingkungan RT 04/06 Cikiwul Bantargebang Bekasi.

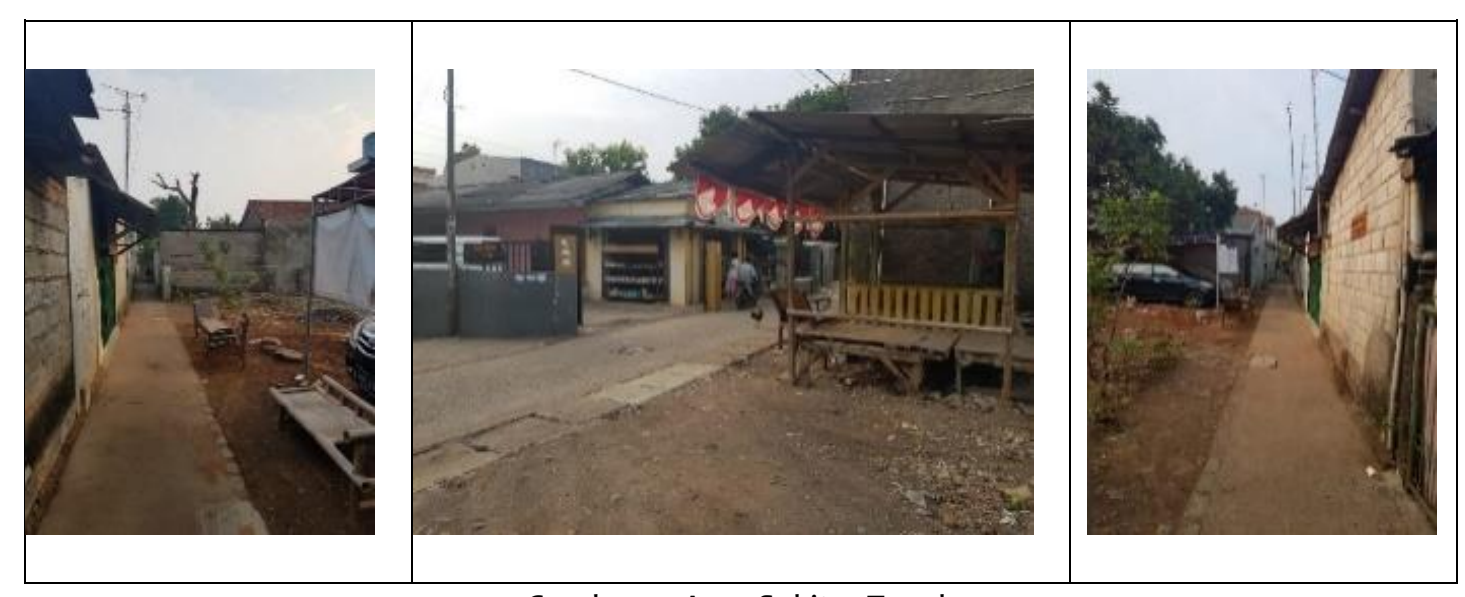

Gambar 3. Area Sekitar Tapak

\section{Tujuan Kegiatan}

Kegiatan ini dilakukan dengan tujuan untuk turut andil dalam merealisasikan desain RPTRA tersebut dalam kegiatan pengabdian masyarakat dengan judul PKM Realisasi Desain RPTRA di Lingkungan RT 04/06 Cikiwul Bantargebang Bekasi.

\section{Kesepakatan Usulan Desain}

Dari permasalahan mitra yang ada, kami tim pengusul mencoba melihat dengan lebih peka dari desain yang telah disepakati. Harapan kami, kami dapat membantu untuk turut andil dalam mewujudkan ruang publik terpadu ramah anak atau selanjutnya disebut RPTRA ini dijadikan salah satu wadah yang menjadi pusat kegiatan khususnya bagi anak-anak agar dapat bermain dengan nyaman, tenang dan aman dan orang tua pun tidak merasa was-was mendampinginya. Dari usulan desain tersebut kami bisa melihat bagian mana yang bisa kami bantu, atau yang paling darurat, atau yang bisa menjadi bantuan stimulus sehingga bisa dikembangkan oleh warga di kemudian hari.

Dari hasil penelusuran kondisi tapak dan kebutuhan aktivitas pada ruang publik maka kami mengusulkan desain RPTRA dengan prioritas user adalah anak anak dan para ibu yang mengawasi anaknya bermain sambal beraktifitas. Secara spesifik kami mengusulkan aktifitas di dalamnya berupa track sepeda dan lapangan bermain serbaguna yang dilengkapi tempat untuk duduk duduk, kebun edukasi anak, namun juga tidak mengalahkan kepentingan warga yang menyimpan mobilnya di dalam site beserta pos ronda eksisting yang diperbaharui. Di dalam site juga ditambahkan pepohonan rindang agar ruang public ini menjadi lebih sejuk dan nyaman untuk digunakan warga. Secara lebih detail berikut adalah konsep desain berdasarkan analisis temuan di lapangan 


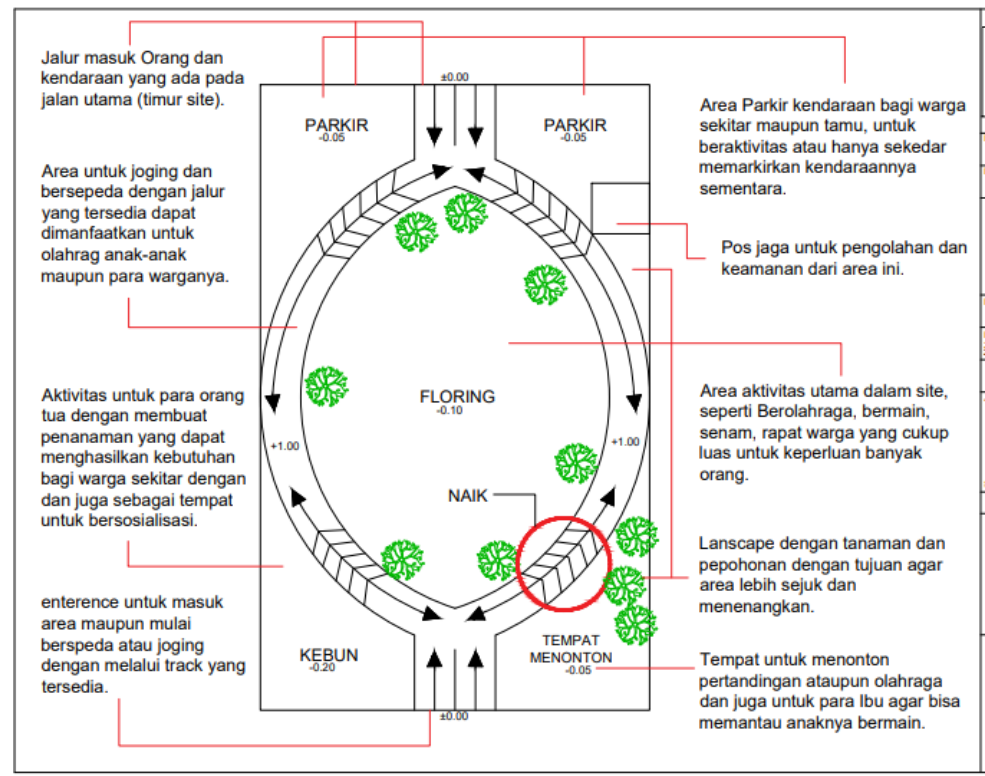

Gambar 4. Konsep Pengembangan Fungsi Lahan

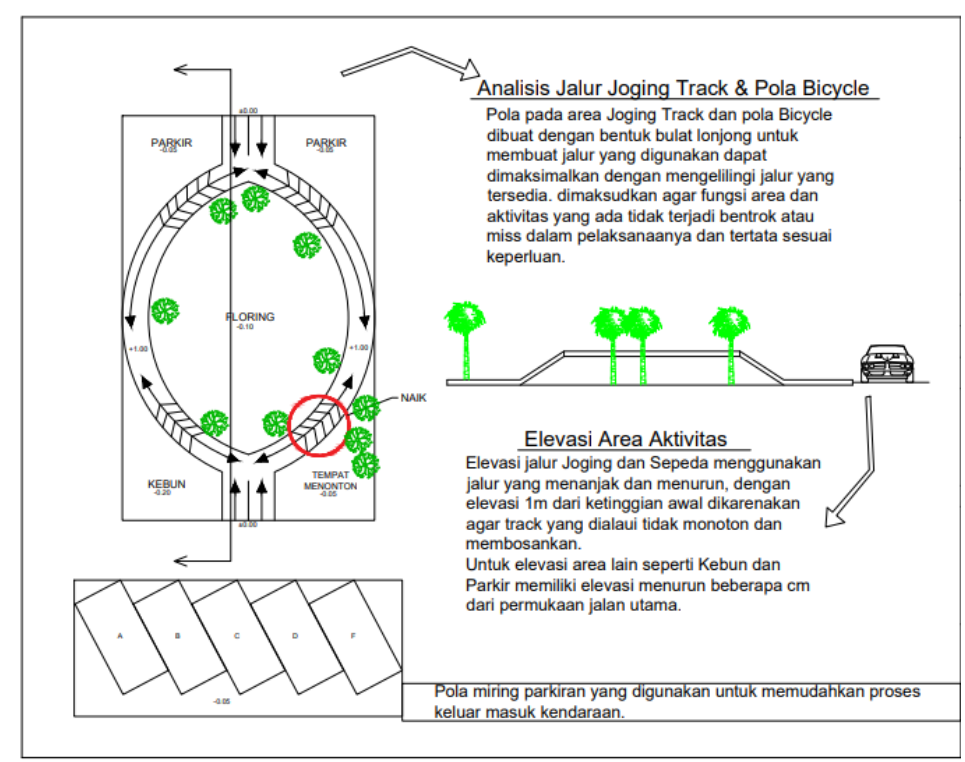

Gambar 5. Konsep Rekayasa Kontur Lahan

Setelah konsep desain disepakati maka tahapan selanjutnya dilakukan dengan membuat produk desain final. Kekuatan utama desain ini terletak pada jalur sepeda bagi anak yang dibuat naik turun dengan mempertimbangkan keamanan berkendara namun tetap menarik bagi anak anak untuk bermain naik turun di jalur sepeda ini. Ditengah jalur sepeda yang melingkar mengelilingi site terdapat sebuah lapangan serbaguna yang dapat digunakan anak anak bermain bola, bermain layangan, juga dapat dilintasi anak anak bermain sepeda, jogging bagi warga, kegiatan lomba 17 agustusan atau kegiatan public lainnya. Peletakan pepohonan sebagai vegetasi peneduh terpusat pada bagian barat site sebagai pelindung sengatan matahari sore, sedangkan pada bagian lainnya di dominasi pohon pengarah seperti palem yang mengikuti pola jalur sepeda. Kebun bumbu dapur dan tanaman 
produktif lainnya tetap kami pertahankan, namun disesuaikan dan ditata ulang sesuai konsep desain. Keberadaan kebun ini juga digunakan sebagai sarana edukasi anak anak untuk mengenalkan kecintaan terhadap lingkungan, mengenal jenis jenis tumbuhan beserta manfaatnya. Bagian eksisting lainnya yang kami akomodir adalah keberadaan pos ronda yang jadi tempat berkumpulnya bapak bapak di sore hari juga sebagaimana Namanya berfungsi sebagai pos ronda pada malam hari. Selain itu juga terdapat parkiran mobil warga yang jumlahnya disesuaikan jumlah mobil pengguina yaitu 5 buah.

Untuk memudahkan warga membaca produk desain dan mengaplikasikannya saat pembangunan, kami tidak menggunakan format gambar kerja yang rumit. Kami memberikan gambar yang mudah dibaca berupa gambar rencana tapak yang sudah diberi grid atau garis bantu yang berjarak per 1 meter. Keberadaan gambar ini akan sangat membantu warga untuk membayangkan posisi ruang sesuai kondisi di lapangan dan memudahkan warga jika akan membuat penyesuaian desain. Gambar pendukung pun disiapkan berupa potongan kontur tapak sehinnga dapat dibayangkan aplikasinya juga gambar ilustrasi desain 3 dimensi beserta keterangan material serta warna yang digunakan.

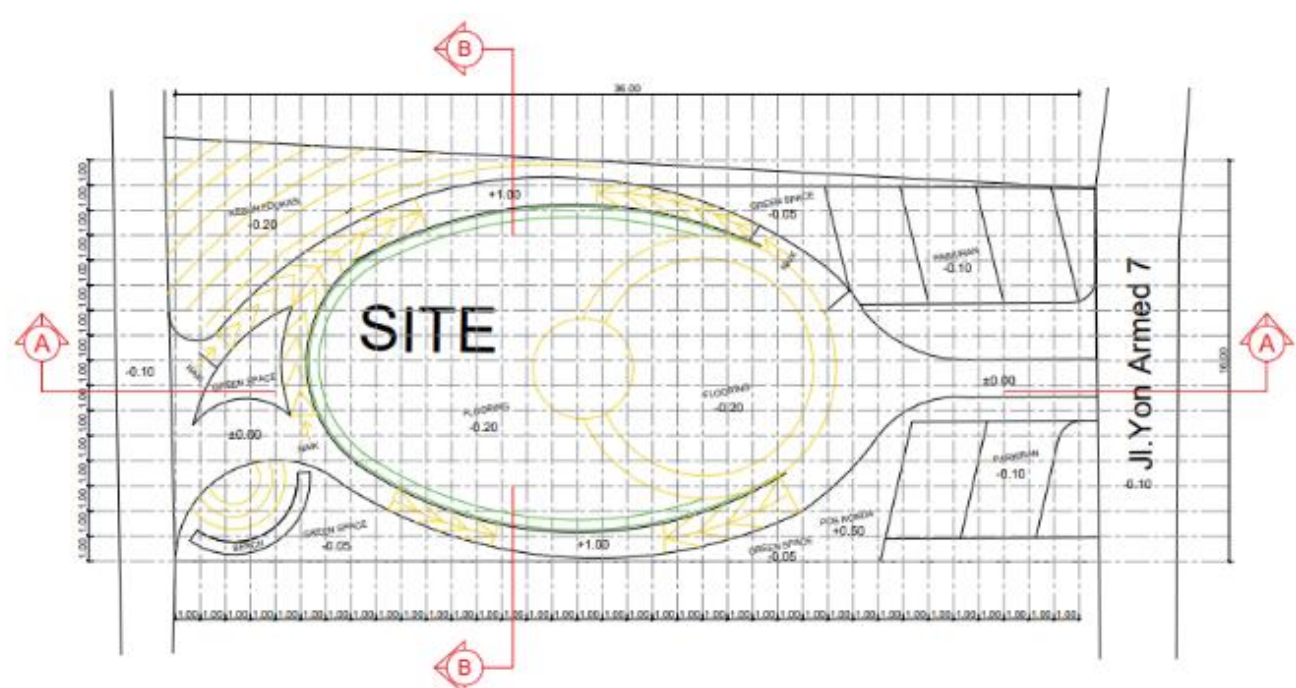

Gambar 6. Gambar Rencana Tapak

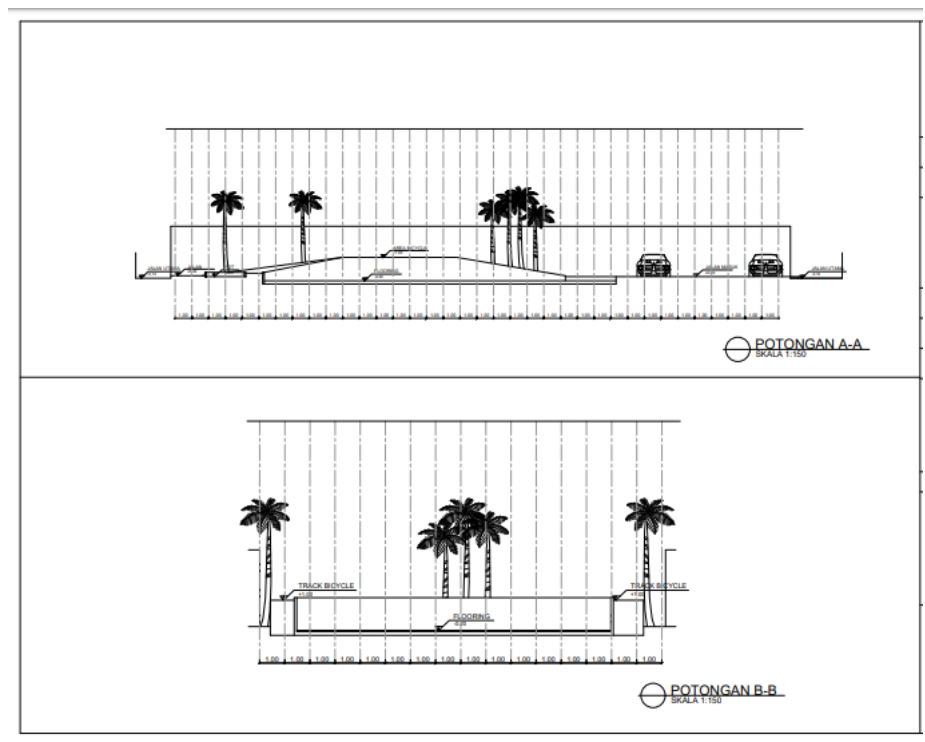

Gambar 7. Gambar Potongan Tapak 
Berikut ini adalah gambar visualisasi tiga dimensi dari perencanaan RPTRA di Rt 04 kelurahan Cikiwul. Keberadaan gambar visual 3d bertujuan membuat warga membayangkan kondisi saat ini dan stelah dibangun nanti, sekaligus penyempurna produk desain yang kami usulkan.

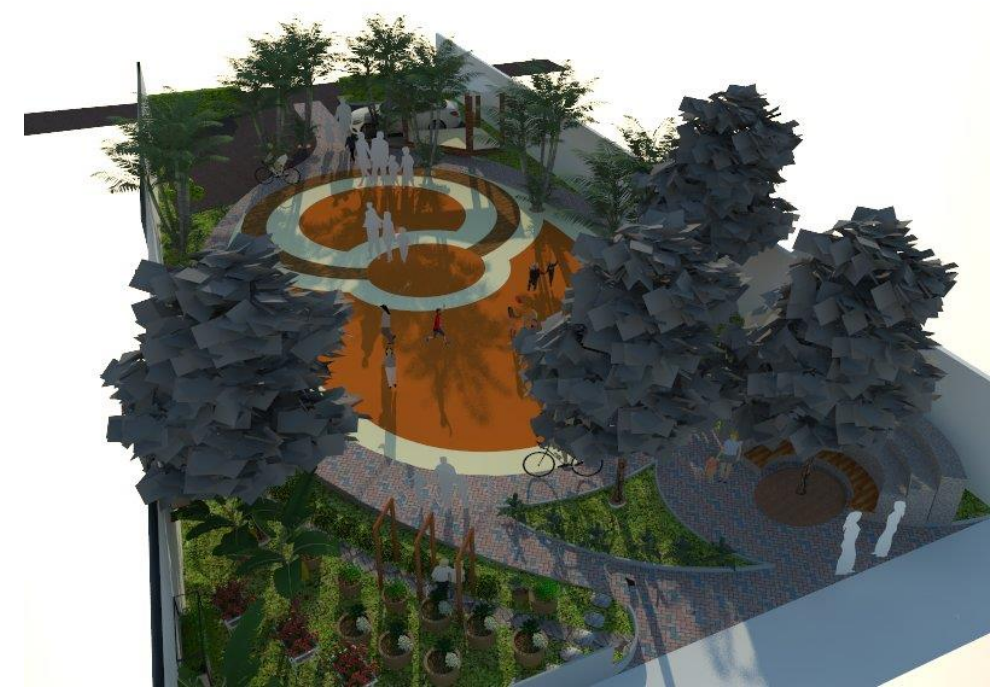

Gambar 8. Ilustrasi Desain Situasi Lingkungan RPTRA
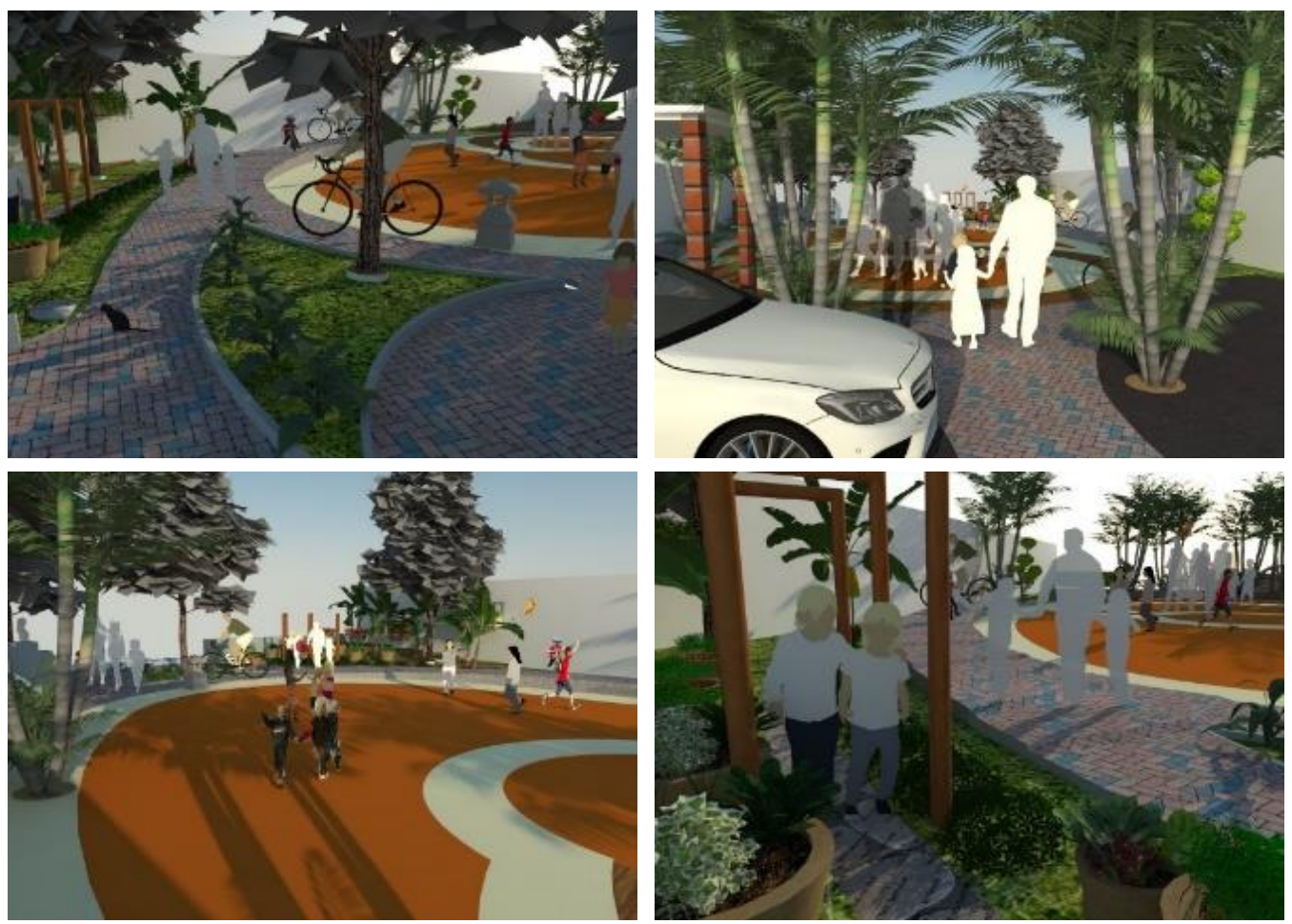

Gambar 9. Ilustrasi Suasana di dalam RPTRA

\section{METODOLOGI}

Kegiatan yang dilakukan diawali dengan menjalin komunikasi dengan mitra untuk meminta kesediaan kerjasama dalam Program Pengabdian Masyarakat LPPM Universitas Indraprasta PGRI Jakarta. Selanjutnya melakukan survey lokasi yang lebih detail ke lingkungan RT 04 RW 06 Cikiwul Bantargebang Bekasi dan diskusi mendalam dengan mitra untuk mengamati dan menganalisis desain 
yang sudah disepakati agar bisa menentukan andil apa yang bisa diberikan dari kegiatan PKM ini. Waktu pelaksanaan Pengabdian masyarakat direncanakan pada Bulan Oktober 2020. Pelaksanaan kegiatan abdimas ini dilakukan langsung oleh warga karena metode yang digunakan adalah participatory walaupun dengan jumlah warga yang berbatas karena kondisi pandemic. Metode ini dipilih agar warga bisa ikut serta terjun langsung dalam proses mewujudkan desain RPTRA melalui tahap awal dengan mengetahui estimasi biaya dari desain ini agar tepat sasaran dan didukung dengan rasa memiliki hingga nanti desain tersebut bisa terbangun dan mengetahui bagaimana pentahapan pembangunan dan pembagian porsi andil dari berbagai stakeholder.

Dalam pelaksanaan abdimas ini, mitra baik ketua RT maupun warga sangat kooperatif dalam melakukan kegiatan ini, warga membantu melakukan pengecekan harga satuan di lingkungan sekitar sehingga estimasi biayanya bisa akurat. Selain itu mitra pun berdiskusi bersama dengan tim pelaksana abdimas bagaimana membagi porsi dan tahapan pembangunan sehingga bisa realistis apalagi di tengah kondisi pandemi seperti sekarang.

Widaningsih dan Barliana mengungkapkan pendekatan partisipatif memiliki peluang untuk mengembangkan dan menjamin suatu komunitas sosial yang memungkinkan terjadinya proses belajar dari masyarakat untuk beradaptasi dan berintegrasi dengan lingkungannya. Masyarakat yang akan tinggal di dalam wilayah dunia-hidup baru yang direncanakan dibina sejak awal oleh arsitek dalam hal ini pelaksana abdimas untuk turut serta, urun rembug dalam perancangan fisik RPTRA ini. Posisi metode partisipatif pada kampung-kota bukan sekedar kebutuhan untuk menciptakan 'rasa saling memiliki, tetapi secara eksistensial mampu membangun pengertian bahwa mereka hidup dalam satu duniahidup yang menjadi rumah mereka selama mungkin. Pendekatan partisipatif tidak hanya dilakukan oleh pelaksana abdimas, akan tetapi menggali dan menumbuhkan partisipasi masyarakat dalam keseluruhan proses kegiatan abdimas karena dalam pendekatan partisipatif dalam penelitian arsitektur harus bermuara pada tujuan akhir bahwa hasil abdimas tersebut dapat diimplementasikan dalam kehidupan masyarakat. Sebagai bagian dari proses tersebut, pendekatan partisipatif juga merupakan pengembangan Community based development yang mengisyaratkan pentingnya penerapan hasil penelitian dan pelaksanaan proses pembangunan yang didasarkan pada kebutuhan masyarakat. Pola seperti itu memungkinkan partisipasi masyarakat dapat dikembangkan secara optimal. Partisipasi masyarakat dilakukan dengan tujuan akhir dari pembangunan masyarakat adalah untuk meningkatkan kesejahteraan penduduknya secara langsung dan secara tidak langsung adalah meletakkan dasar-dasar pembangunan daerah dan pembangunan nasional.

\section{HASIL DAN PEMBAHASAN}

Dalam melakukan kegiatan pengabdian masyakarakat ini banyak perubahan yang dilakukan dari rencana karena terkait kondisi darurat yakni pandemi virus Covid-19 ini. Kami sebagai tim pengabdi dan mitra pun berusaha berpikir keras agar kegiatan ini bisa terus dilaksanakan karena sayang sekali untuk mematahkan harapan dan semangat warga supaya bisa memiliki Ruang Publik Terpadu Ramah Anak yang selama ini diinginkan. Langkah realisasi yang kami lakukan akhirnya adalah melakukan perhitungan akurat atau disebut Rencana Anggaran Biaya (RAB), menentukan tahapan pembangunannya dan menentukan andil setiap stakeholder dalam pembangunan ini. Langkah ini diambil karena dirasa hal ini bisa menjadi langkah awal yang krusial serta sangat memegang peranan penting dan bisa digunakan untuk mencari donator yang berkenan menyumbangkan dana atau barang material dalam pembangunan RPTRA milik warga ini.

Pada bagian ini dijelaskan mengenai tahapan Pembangunan yang telah disepakati berikut Rancangan Anggaran Biaya Pembangunan RPTRA Cikiwul. Secara garis besar realisasi RPTRA ini 
terbagi empat tahapan dan setiap tahapan pekerjaaanya terbagi atas pekerjaaan yang dilakukan swadaya oleh warga dan pekerjaaan yang dilakukan oleh tukang bangunan. Untuk proses pengerjaan setiap tahapan belum dapat ditentukan secara pasti, mengingat kondisi pandemi saat ini yang berdampak pada perekonomian warga dan produktifitas warga dalam kegiatan social. Oleh karena itu kami tim pengabdi mengusulkan tahapan pembangunan sesuai dengan sasaran pembanguan dan dampak yang dirasakan warga, sehingga dapat menjadi pemicu untuk meneruskan pada tahap berikutnya.

Tahapan pertama, kami sebut sebagai tahap persiapan. Di sini sasaran utamanya adalah menggerakan warga untuk terlibat aktif dalam proses perwujudan RPTRA ini dengan biaya seminim mungkin, namun dapat memberikan dampak signifikan terhadap warga. Berdasarkan kalkulasi Rancangan Anggaran Biaya, di[perkirakan pada tahap pertama ini membutuhkan dana sekitar empat juta rupiah.

Pada penggambaran kondisi eksisting, lahan inidapat dikatakan sebagai lahan tidur yang dipergunakan bersama untuk kepentingan masing masing. Sepeerti yang kita ketahui lahan lebih banyak digunakan warga untuk parkir mobil, membuang puing hasil bongkaran bangunan, hingga membuang sampah. Namun ada juga yang memanfaatkan untuk menanam tanaman produktif seperti pohon buah dan tanaman palawija seadanya. Mengacu pada konsep desain dimana lahan ini dapat dimaksimalkan penggunaannya oleh warga secara bersama sama dan untuk kepentingan bersama bukan lagi individu. Untuk itu di tahapan pertama ini yang dilakukan terlebih dahulu adalah mempersiapkan lahan untuk bisa digunakan. Secara kongkrit pada tahap ini warga akan terlibat langsung dalam pembersihan lahan dari sampah maupun puing bangunan yang berserakan di berbagai bagian dari lahan, dan dilanjutkan dengan membentuk kontur lahan, terutama pada jalur sirkulasi sesuai dengan desain. Proses pengerjaaan dilakukan secara swadaya oleh warga dan dipimpin oleh ketua RT setempat. Tujuannya adalah agar warga merasa memiliki fasilitas bersama dan kelak akan menjaga fasilitas yang dibangun bersama. Agar memberikan dampak signifikan terhadap warga, kegiatan krusial pada tahap pertama dititikberatkan pada pematangan lahan taman toga dengan mengganti tanah pasir dan puing menjadi tanah merah dan pupuk serta penanaman tanaman produktif di dalamnya.

Setelah dampak dari tahapan pertama selesai dan kas pembangunan infrastuktur siap, barulah tahap kedua dapat dilaksanakan. Dalam tahap kedua sarasannya adalah pembanguna fasilitas yang dapat dipergunakan warga secara bersama sama. Oleh kareana itu lapangan olahraga dan parkiran dipilih sebagai sarana bersama yang dibangun terlebih dahulu. Harapannya dengan keberadaan lapangan olahraga, anak anak dapat bermain di lapangan dengan aman tanpa takut tertabrak kendaraan dibandingkan jika bermain di jalan. Selain itu lapangan olahraga juga dapat dimanfaaatkan warga untuk kegiatan rutin mingguan seperti senam pagi dan seterusnya. Harapannya pembangunan lapangan ini dapat terealisasi sebelum Bulan Agustus agar dapat digunakan dan diresmikan dengan kegiatan HUT kemerdakaan RI oleh warga. Momen ini dianggap sangat special jika terealisasi, karean setiap tahunnya kegiatan menyambut Hari kemerdekaan tidak pernah dilakukan secara terpusat untuk skala RT dan lebih kepada inisatif sebagian warga saja untuk mengadaka kegiatan lomba maupun lainnya setiap tahun. Dengan adanya sarana bersama diharapkan dapat menjadi momen untuk menyatukan kegiatan yang sebelumnya dilakukan secara terpisah pisah, dan akan dikoordinir oleh pengurus RT. Untuk pembangunan sarana lapangan olah raga ini diperkirakan akan menghabiskan dana sekitar delapan puluh satu juta rupiah. Dalam pengaplikasiannya warga dilibatkan dalam proses pemadatan lahan, pembangunan pos jaga, dan pengecatan lapangan. Sisanya akan 
dikerjakan oleh tukang bangunan agar hasil pekerjaannya dapat maksimal dan bertahan dalam jangka waktu yang lama.

Tahap ketiga merupakan tahap penyelesaian sarana lingkungan. Pada tahapan ini sasarannya adalah fungsi lahan dimaksimalkan dengan penambahan sarana berupa jogging track sekaligus jalur sepeda berbukit bukit yang dapat menarik perhatian anak anak untuk bermain. Agar para orangtua dapat mengawasi sambil berinteraksi dengan warga lainnya juga dibangun bangku taman dibawah pepohonan rindang. Untuk menyelesaikan tahapan ini anggaran yang dibutuhkan adalah sekitar dua puluh dua juta rupiah. Dengan keberadaan tambahan jalur sepeda dan jogging track ini diharapkan warga dapat menggunakannya secara maksimal unuk kegiatan olah raga maupun interaksi social didalamya, dengan demikian proses place making di RPTRA ini dapat berjalan secara maksimal. Adapun pembagian porsi pekerjaan yang dilakuka secara swadaya oleh warga meliputi pekerjaan simulasi kontur jalan berbukit dan pemadatan lahannya, sedangakan eksekusi final dalam proses pembuatan jalan serta bangku taman dikerjakan oleh tukang. Rencananya pembuatan jogging tracksekaligus jalur sepeda ini akan menggunakan paving block, sehingga jika ada kerusakan lebih mudah perawatan serta perbaikannya secara parsial. Sayangnya proses pembangunan tahap ketiga ini kemungkinan tidak dapat dilakukan pada tahun yang sama, mengingat dana kas RT dan donasi warga yang digunakan sudah sangat besar di tahapan sebelumnya, sehingga alokasi anggaran untuk RPTRA ini harus menunggu tahun berikutnya. Proses pembangunan tahap ketiga ini mungkin saja dipercepat jika manfaaatnya dirasakan secara signifikan oleh warga dan mendapatkan skala prioritas dalam penyelesaiannya. Scenario lainnya adalah pembangunan tahap ketiga ini berjalan berdampingan dengan tahapan keempat jika dananya tersedia.

Tahap keempat atau dapat kita sebut sebagai tahap penyempurnaan. Pada tahapan ini sasarannya adalah memaksimalkan fungsi fasilitas yang ada adalam RPTRA ini untuk digunakan dalam berbagai kondisi, sekaligus mempercantik dan membuatnya terliahat asri. Adapun yang dikerjakan dalam tahapan pembangunan ini meliputi sarana resapan dan jaur buangan air hujan lingkungan, sarana penerangan lingkungan yang membuat fasilitas ini dapat digunakan pada malam hari, juga pekerjaan taman untuk mempercantik lingkungan. Anggaran yang dibutuhkan untuk menyelesaikan tahapan penyempurnaan ini adalah sekitar enam belas hingga tujuh belas juta rupiah. Untuk teknis pelaksanaan tahapan ini bisa saja berdampingan dengan tahap ketiga atau berjeda beberapa bulan. Untuk pembuatan taman berbukit maka dibutuhkan pengurugan tanah merah lalu ditanami tanaman penutup tanah dan beberapa jenis tanaman pagar. Lalu dilanjutkan dengan penanaman tanaman berbunga seperti tabebuia, atau kamboja bali. Untuk memaksimalkan fungsi lapangan dan jalur sepeda maka penerangan lingkungan diterapkan dengan menempatkan beberapa lampu di titik titik strategis dan mencegah terjadinya titik buta yang berpotensi menimbulkan dampak yang tidak diinginkan. Pembangunan beberapa sumur resapan juga dilakukan untuk memperbaiki cadangan air tanah atau sebagai bank penampungan air hujan lingkungan. Untuk mencegah terjadinya genangan pada saat hujan besar maka di sekitar lapangan ditambahkan system drainase atau jalur pembuangan air hujan. Ketika keempat tahap ini selesai dibangun maka selesai pula seluruh proses pembangunan RPTRA Cikiwul dan proses pembangunan bertahap ini akan membantu proses Place making dan menggeser pola kehidupan warga menjadi lebih baik. 


\section{PENUTUP}

Simpulan

Dalam kegiatan abdimas seperti ini memang lebih mudah jika bisa melibatkan banyak pihak sehingga bisa membangun kerja sama yang baik demi terwujudnya tujuan dari kegiatan ini. Seperti pada kegiatan ini pihak mitra sangat membantu setiap proses sehingga walau dalam kondisi berat yang kita alami bersama yakni keterbatasan ruang bertemu karena pandemi serta keterbatasan dana tidak mengurangi semangat warga untuk bisa mewujudkan RPTRA ini. Kegiatan ini dilakukan agar setiap dana yang dikeluarkan dalam setiap tahapnya bisa dimanfaatkan untuk pekerjaan yang efektif sehingga tidak ada yang terbuang dalam prosesnya. Pembagian porsi andil pembangunan pun menjaga agar setiap langkah yang dilakukan tidak tumpeng tindih.

\section{Saran}

Setiap kita melakukan kegiatan yang berkaitan dengan warga apalagi kepentingan publik baiknya kita bisa memposisikan diri sebagai fasilitator sehingga warga atau mitra kita di sini bisa lebih terbuka dalam mengutarakan ide dan saran terkait program yang sedang dilaksanakan.

\section{DAFTAR PUSTAKA}

Arendt, H. (1986). Communicative Power. In S. Lukes (Ed.), Power. . Oxford: Basil Blackwell Ltd.

Cowen, M., \& Shenton, R. (1996). Doctrines of Development. London: Routledge.

De Certeau, M. (1993). Walking in the City. In S. During (Ed.), The Cultural Study Reader. . London and New York: Routledge.

Elyda, C., \& Budiari, I. (2015, September 17). Jakartans Enthused with New RPTRA COmmunity Centers. The Jakarta Post.

Jones, P., Petrescu, D., \& Till, J. (2012). Architecture and Participation. London and New York: Routledge. Lefebvre, H. (1996). Writing on Cities. Oxford: Blackwell Publisher

PPA, B. (2014). Proposal. Jakarta: Badan Pemberdayaan Masyarakat, Perempuan dan Keluarga Berencana Sanders, Elizabeth B-N; SonicRim. (2002). From User-Centered to Partisipatory Design Approach. Dalam J. Frascara, Design and Social Sciences: Making

Connections. London And New York: taylor and Francis

https://megapolitan.kompas.com/read/2017/06/28/15092351/satu.lagi.fasilitas.publik.rptra.ke muning.hadir.di.pejaten.timur. 